Figure S12. Low Resolution Mass spectra of GA-XIV (4) (ESI+).

\section{4-Jul-2013 10:01:10}

GUE_GA-XIV 21 (0.570) Cm (18:27)

100

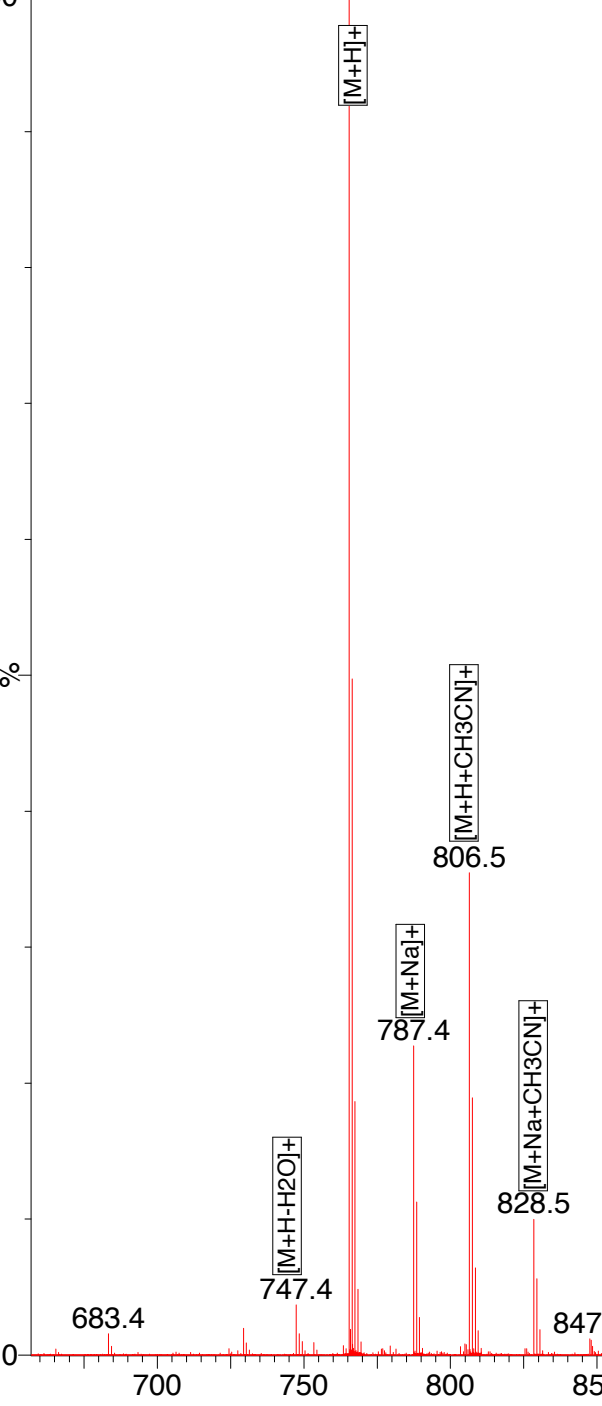

$\mathrm{MeOH} / \mathrm{H} 2 \mathrm{O}$

LCT Premier XE KE483 1: TOF MS ES+

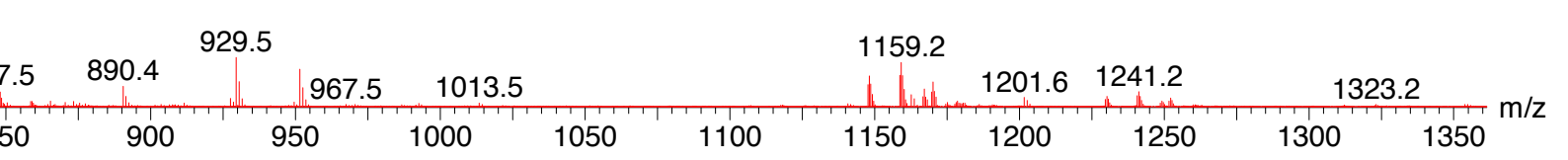

